\title{
CROSS-PARTY COLLABORATION TO REDUCE CONSTRUCTION WASTE TO DESIGN-BUILD PROJECTS
}

\author{
Afrizal Nursin ${ }^{1 *}$, Yusuf Latif $^{1}$, Krishna Mochtar ${ }^{2}$, Hari G. Soeparto ${ }^{1}$ \\ ${ }^{1}$ Department of Civil Engineering, Faculty of Engineering, Universitas Indonesia, Kampus UI \\ Depok, Depok 15424, Indonesia \\ ${ }^{2}$ Civil Engineering Study Program, Indonesian Technology Institute, Kampus Institut Teknologi \\ Indonesia Jl. Raya Puspiptek Serpong, Tangerang Selatan, Banten 15314, Indonesia
}

(Received: March 2018 / Revised: April 2018 / Accepted: July 2018)

\begin{abstract}
Waste in the construction industry is a severe problem in various countries in the world, including in Indonesia. Several studies on construction projects over the last three years have found that the Construction Waste $(\mathrm{CW})$ tendency has increased significantly. The objective of this study is to identify existing CW in design-build project and how it can be reduced by increasing collaboration between the stakeholders involved in such projects. The survey method is used to explore and find solutions to the $\mathrm{CW}$ problems, and to reduce it by increasing collaboration. Data were obtained from 127 respondents working on a design-build construction project, then processed by using the SEM-PLS 3.0 Professional program to estimate the causalpredictive relationships between stakeholder, culture, communication, conflict, and the collaborative variables that affect the reduction in construction waste on design-build project. A collaborative model between the parties implemented by managing those involved, understanding the culture, minimizing conflict and improving communication, can reduce both physical waste and non-physical construction waste.
\end{abstract}

Keywords: Collaboration; Conflict; Construction waste; Design-build

\section{INTRODUCTION}

Collaboration involves parties with various interests working together to achieve the desired outcome with the ultimate goal of mutual satisfaction. In the interests of the parties, there is an interest, where the explanation of interest is what is cared for or desired by each party. Many names or titles know collaboration. Some popular names include "problem solving", "consensus", "desire-based negotiation", "win/win", "mutual benefit", and "principled negotiation". (Fisher et al., 1991; Burgess \& Burgess, 1997). The purpose of the collaboration is to manage cooperation in a multi-stakeholder, more constructive activity, where the outcome fosters effective communication in problem-solving and enhances relationships among the parties (Coser, 1956). Collaboration is everywhere its presence in our lives is a permanent feature of modern society; Work is always social in the sense that objects and subjects, end and understood, reason and need, application and ability, are form of social mediation (Harshada et al., 2011).

One of the recommendations presented by Berawi (2017) to improve infrastructure development strategies and programs, is to enhance the role of universities in

\footnotetext{
*Corresponding author's email: nursin_afrizal@yahoo.com.sg, Tel. +62-81586113660, Fax. +62-217863532 Permalink/DOI: https://dx.doi.org/10.14716/ijtech.v9i4.1819
} 
collaborating with governments and industry to strengthen planning and development of infrastructure and connectivity programs. This means that in the future the problem of collaboration in infrastructure development is fundamental (Berawi, 2017).

In this paper, the collaboration is aimed at reducing Construction Waste (CW) which is a crucial issue in the construction industry environment. CW is considered at an early stage of the project, by all parties involved in the development process (Poon, 2007). A simplified approach emerging in controlling CWs is to use environmentally friendly construction methods. That aim to reduce waste generation during construction stages, such as using panel systems, applying prefabricated components and reducing the use of natural materials (Peng et al., 1997). Support for cutting $\mathrm{CW}$ is one of the best and most efficient methods to minimize its growth and eliminate many of its associated problems. Therefore, in construction projects with uncertain, a high degree of confidence and collaboration can lead to increased efficiency (Kadefors, 2004).

The various aspects of residential construction, design, use, and destruction can have a significant impact on the environment. Sustainable development is impossible without sustainable buildings and housing. Cultural issues of the sections to consider in the process, as explained that sustainable housing development can be understood on ecological, economic, technological, cultural and social sustainability (Bakar et al., 2011).

The problem and research question for this study are: what collaboration between the parties can be applied to the Designed Build project to reduce CW?

In detail there are four questions to be studied, namely:

a) RQ1: What is the platform for creating collaboration of parties on the Design-Build project?

b) RQ2: What is the significance of various stakeholders in the Design-Build project?

c) RQ3: Do communication and conflict affect the implementation of collaboration?

d) RQ4: Does the collaboration model affect the reduction of construction waste?

\section{LITERATURE REVIEW}

\subsection{Project Design Build}

The design-build contractor starts construction after completing the design details. On intermediate inspection, verification is made by the parties involved in the project. The design culminates in the preparation and completion of the drawings and specifications used to complete the project. Owners or agents, such as architects/engineers or construction managers, monitor the construction progress, and ensure approval for payments as the construction progresses. On completion of the construction, there is an acceptance inspection, followed by commissioning facilities for the use of the owner. The planners, supervisors/Constitutional Court, sub-contractors, and suppliers rely wholly on the coordination led by Project Design Manager Contractor for them to be able to collaborate. The engineering and construction process constitutes the elements that determine the success of the project, so each of these has parameters of success.

The Construction Industry Institute conducted a comparative study of 351 projects ranging from $5,000 \mathrm{sq} \mathrm{ft}$ to $2,500,000 \mathrm{sq} \mathrm{ft}$, representing various project types and sectors. It was found that design and build projects perform better with regard to unit price indicators, construction speed, project delivery speed, incremental cost, and increased time or project delay, as shown in Table 1 (Construction Industry Institute, 2018). 
Table 1 Comparison of project delivery method

\begin{tabular}{lrlcl}
\hline \multirow{2}{*}{ Metric } & \multicolumn{2}{c}{ Design and Build VS. } & \multicolumn{2}{c}{ Design and Build VS. } \\
& \multicolumn{2}{c}{ Design-Bid-Build } & \multicolumn{2}{c}{ CM@Risk } \\
\cline { 2 - 5 } & Percentage & Value & Percentage & Value \\
\hline Unit Cost & $6.100 \%$ & Lower & $4.500 \%$ & Lower \\
Construction Speed & $12.000 \%$ & Faster & $7.000 \%$ & Faster \\
Delivery Speed & $33.500 \%$ & Faster & $23.500 \%$ & Faster \\
Cost Growth & $5.200 \%$ & Less & $12.600 \%$ & Less \\
Schedule Growth & $11.400 \%$ & Less & $2.200 \%$ & Less \\
\hline
\end{tabular}

Advantages of the design-build delivery method include the facts that: (1) the general design of the project delivery system is the fastest; (2) there is a single entity responsible for design and construction; (3) there is an initial fee and schedule agreement; (4) any conflict between project professionals remains internal and excludes owners (Forbes \& Ahmed, 2011).

\subsection{Construction Waste}

Nagapan et al. (2012) concluded that CW consists of physical and non-physical waste. Physical waste goods arise from incompatibility between the design module and existing product standards; for example triplex $1.20 \mathrm{~m}$ wide and $2.40 \mathrm{~m}$ long made for teakwood double doors measuring $0.80 \mathrm{~m}$ wide and $2.10 \mathrm{~m}$ long. The triplex will be mostly wasted and not be able to be used for other doors. There are many other examples of manufactured goods which do not align with design modules, such as ceramics, iron and concrete.

Non-Physical Waste (NPW) consists of time overrun and cost overrun. It should be understood that the notion of time overrun is related to the time available to undertake production activities, and when workers are unable to complete the work in this time, so the construction activities cannot be finished by the planned date. Cost overrun is related to the utilization of funds or expenses for construction activities which exceed the proposed budget (Nagapan et al., 2012).

Physical Construction Waste (PCW) is defined as waste arising from construction, renovation and demolition activities, including excavation of land or land formation, civil and building construction, land clearing, demolition activities, road repairs and renovation buildings (Shen et al., 2004; Tam \& Tam, 2008; Kofoworola \& Gheewala, 2009). Some of this is defined as solid waste; inert waste comprising mainly sand, bricks, blocks, steel, concrete debris, tiles, bamboo, plastics, glass, wood, paper, vegetation and other organic materials (Bossink \& Brouwers, 1996; Hao et al., 2008; Baum \& Katz, 2011). Another way to understand waste or physical construction debris is by observing the construction site. Type of waste in the form of loss of complete building materials, because the facts show when repaired damaged again or can not be used again. Waste is usually removed from the site to landfills.

\subsection{Stakeholder}

Stakeholder analysis is a systematic process of collecting and analyzing qualitative information to determine who should be taken into account when developing and implementing policies or programs (Schmeer, 1999). It is conducted by a process that begins with identifying key stakeholder projects, assessing their interests, and establishing how the benefits affect the project risk and feasibility level. It contributes to project design by defining the goals and roles of different groups, and by helping formulate appropriate forms of engagement with these groups.

Stakeholders can be divided into two groups: groups within the Design-Build Company, called internal stakeholders; and those outside the company, called external stakeholders. Stakeholder analysis is one (though usually the first) step in building the relationships necessary for the 
success of a project or participatory policy.

Stakeholder analysis of a project requires the following activities, among others (Jepsen \& Eskerod, 2009): (1) identification of the stakeholders (important); (2) characterization of the stakeholders (needed support, expectations related to respect for support, strength in relation to the project), (3) decisions on strategies to be used to influence stakeholders.

\subsection{Collaboration of the Parties}

It is inevitable that the construction industry faces complexity in carrying out its mission, so the idea of collaboration is essential. Much of the discussion on stakeholder collaboration centres on the harmonization of design, regulations, use of technology and performance, with less focus on the processes, dynamics and social aspects of the contract (Shenkar \& Yan, 2002; Nicolajsen, 2007). Collaboration between parties is on a cross-organization/industry basis, and is shown to enhance capabilities and generate value for the organization through the exchange of resources, thereby supporting its competitive advantage (Elmarsafi, 2008).

Some theorists believe that value creation occurs when new situations create unique needs for the exchange of resources, including information. Where the context is often discussed regarding a prescription where the organization collaborates for implement innovation. Collaboration between parties to achieve minimize costs. Most of the suggestions made suggest that there are benefits and lack of collaboration between parties. Moreover, many factors should be applied to collaboration between parties in the work. However, in the construction industry a minimalist co-operation is required, it will show that the conditions for collaborative practice have matured.

To create a competitive advantage strategy in the industry is to enhance or enhance interorganizational collaboration. The current partnership strategy, a regular business strategy with over 10,000 partnerships created annually in the United State. (Schifrin, 2001). In industries such as the construction industry, which undeniably confront most of the complexity of any industry in carrying out its mission, the idea of collaboration is crucial.

\subsection{Concept of Conflict}

Egan and Yasamis, convey that: poor productivity, cost overruns, degradation of construction quality, decreased customer satisfaction, conflicts, and final settlements are part of the problem in the construction sector (Egan, 1998; Yasamis et al., 2002). It is motivated by differences in the characteristics that individuals bring to an interaction. These differences include physical features, intelligence, knowledge, customs and beliefs. Conflict and integration work as a cycle in society, and controlled conflict will result in an alliance. Conversely, an imperfect combination can create conflict.

\subsection{Communication}

According to Rowley (as cited by Edah, 2009), communication competence is the ability to send messages that support the achievement of goals while maintaining social acceptance. The definition of communication competence from the behavioral perspective was formulated by Wiemann and Backlund as an individual's ability to demonstrate knowledge of appropriate communication behavior in a given situation (Edah, 2009). While Payne in (Edah, 2009) defines the communication competencies formulated, that is, the set of abilities henceforth termed resources, which a communicator has available for use in the communication process.

The communication process can: (1) clearly identify the project; (2) identify stakeholder communications needs; (3) execute the types of communication activities to send messages; and (4) ensure the right people are available at the right time (Caltrans, 2007). 


\subsection{Cultural Concepts}

Current Construction Management programs in higher education provide technical and management knowledge to students. However, in the twenty-first century construction professionals must be familiar with the cultural, environmental and political factors that can influence international projects, and know how to work efficiently in the global arena (Xue et al., 2014). Koentjaraningrat (2009) explains that the word "culture" derives from the Sansakerta word "buddhayah," which is the plural form of "buddhi", meaning "mind" (Koentjaraningrat, 2009).

Hofstede (2017) defines culture as "the collective programming of the mind that distinguishes members of one group or category of people from others." In 1980 he published the book Culture's Consequences: The International Difference in Work-related Values; as the title suggests, , it is entirely devoted to the study of culture at the national level, where values used a significant (Hofstede, 2017).

National identity is built on awareness, so concrete efforts can be made to develop a nation's (in this case Indonesia's) creativity by the following actions (Erwin, 2012): (1) seeking to implement a sense of nationality in the form of nationalism or total devotion to Indonesia, for example by cultivating the use of the Indonesian language; (2) modifying Indonesian culture into something useful to use; and (3) be selective in accepting the influence of globalization that goes to Indonesia.

\section{METHODS}

Research strategies are needed to answer specific research questions. Yin (2009) states that three conditions will affect the type of research strategy, namely: (1) the type of research questions; (2) the controls owned by the researcher of the actual event behavior to be studied; and (3) the focus on contemporary events, as opposed to historical facts.

Yin (2009) also divides the research method into five parts. The five ways are experimental research methods, survey, analysis, historical and case studies, the three conditions that affect the type of research strategy selected earlier against every kind of research strategy.

From the above explanation for this research used survey method. This survey method is conducted to identify the variables in collaboration design-build project, that affect the reduce $\mathrm{CW}$. Identify these variables based on the questionnaires filled out by the respondents. The questionnaire, which is a research instrument, is formulated based on the variables described into indicators and sub-indicators, to be transformed into questions.

This research uses the survey method, which was conducted to identify the collaboration variables that affect the reduction in $\mathrm{CW}$. These variables were identified based on the questionnaires completed by the respondents. The survey, which is a research instrument, was formulated with the variables divided into indicators and sub-indicators, then transformed into questions. The study is a case study of design-build projects, particularly infrastructure projects and high-rise building projects in Jakarta, Indonesia.

The data analysis consists of testing, and categorizing or recombining the evidence to designate the initial study proposition. The data were analyzed cross-case in order to obtain the level of relationships between variables and $\mathrm{CW}$. In this way, the most correlated variable influence on collaboration in reducing $\mathrm{CW}$ would be obtained. To obtain valid results, validation was be in the form of expert opinions, a literature review, and statistical validation. From the results, a conclusion was drawn that answers the research questions previously set. The research process is shown in Figure 1. 


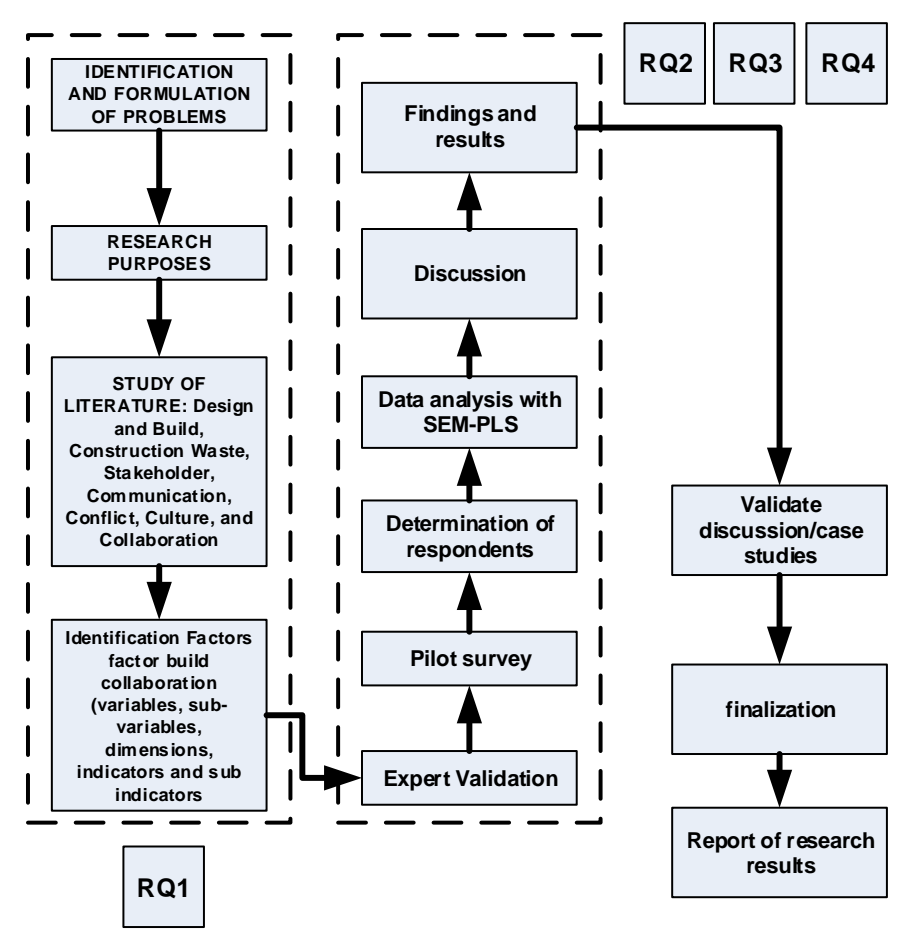

Figure 1 Research process

\subsection{Relationship Research Question and Hypothesis}

The research process was conducted through the preparation of research instruments, expert validation of the instrument, a pilot survey, and data collection through selected respondents from the design and build construction projects. Data were obtained by using SEM-PLS 3.0 Professional to obtain the relationship between the variables.

There are seven research variables covering the stakeholder dimension (variable $\mathrm{X}$ has 92 indicators); culture (variable $\mathrm{B}$ has 26 indicators); communication (variable $\mathrm{K} 1$ has 19 indicators); conflict (variable $\mathrm{K} 2$ has 25 indicators); and building collaboration between parties involved in a design project (variable $\mathrm{C}$ has 98 indicators). It is expected that these will to be able to prove that collaboration can be developed in a structured manner with a strong concept, with its success proven by the two remaining variables: its influence on the reduction of physical waste (variable Y1 has 7 indicators).

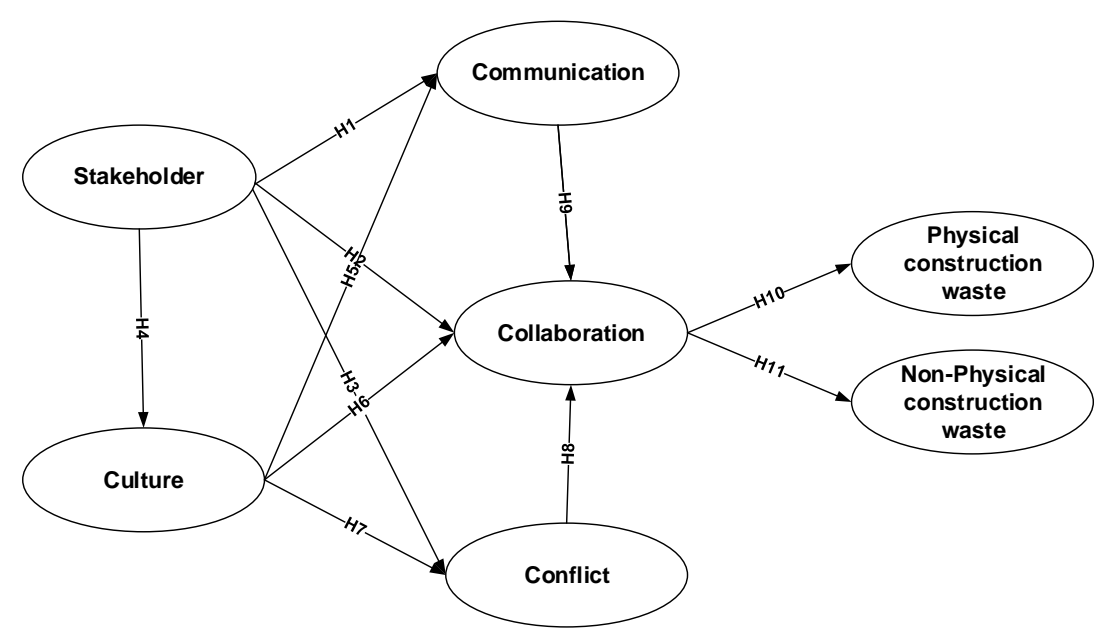

Figure 2 Conceptual research diagram 
The questionnaire distributed was the result of an improved pilot questionnaire to ensure that the variables were easily understood. The respondents at the third stage of data collection were executors of the building projects and infrastructure work carried out using the design-build delivery system. The questionnaires were distributed to 200 respondents; 100 working on building projects, and 100 on infrastructure projects. Of these, 63 of the former were returned, and 64 of the latter; all the respondents were involved in design and build projects.

As can be seen in Figure 2, the relations between the variables explain the formulation of the 11 hypotheses (H1 to H11), and this form of relationship will be able to answer the overall RQ. The relationship between the RQ and hypotheses is shown in Table 2.

Table 2 Relationships between variables explain the existence in the form of 11 hypotheses

\begin{tabular}{cl}
\hline $\begin{array}{c}\text { Research Question } \\
\text { (RQ) }\end{array}$ & \multicolumn{1}{c}{ Hypotheses } \\
\hline & H2: Stakeholders have a positive effect on collaboration. \\
RQ1 & H6: Culture has a positive influence on collaboration. \\
& H8: Conflicts have a negative effect on collaboration. \\
& H9: Communication has a positive effect on collaboration. \\
RQ2 & H1: Stakeholders have a positive influence on Communication. \\
& H3: Stakeholders have a positive influence on Conflict. \\
& H4: Stakeholders have a positive influence on Culture \\
RQ3 & H5: Culture has a positive influence on communication. \\
& H7: Culture has a positive influence on conflict. \\
& H8: Conflicts have a negative effect on collaboration. \\
& H10: Collaboration has a positive effect on the reduction of physical CW. \\
RQ4 & H11: Collaboration has a positive impact on the reduction of Non- \\
& Physical CW. \\
\hline
\end{tabular}

\section{RESULTS AND DISCUSSION}

\subsection{Results}

\subsubsection{Homogeneity test}

The data in Table 3 shows the percentage of homogeneity value of respondents' answers based on: work experience, position and education level. Furthermore, a Mann-Whitney test was conducted to observe homogeneity based on three possible alternative variables. Based on homogeneity test results, there is no need to do scatterplot test because there is no difference of respondent understanding. So it can be concluded $\mathrm{HO}$ accepted; ie, respondents' perceptions do not differ based on: work experience, position, and level of education.

Table 3 Homogeneity test

\begin{tabular}{|c|c|c|c|c|c|c|c|c|c|}
\hline \multirow{2}{*}{ Variable } & \multicolumn{3}{|c|}{$\begin{array}{l}\text { Respondents based on work } \\
\text { experience }\end{array}$} & \multicolumn{3}{|c|}{$\begin{array}{l}\text { Respondents based on the } \\
\text { position }\end{array}$} & \multicolumn{3}{|c|}{ Respondents based education } \\
\hline & Indicator & $\begin{array}{c}\text { Not } \\
\text { uniform }\end{array}$ & $\begin{array}{c}\% \\
\text { uniform }\end{array}$ & Indicator & $\begin{array}{c}\text { Not } \\
\text { uniform }\end{array}$ & $\begin{array}{c}\% \\
\text { uniform }\end{array}$ & Indicator & $\begin{array}{c}\text { Not } \\
\text { uniform }\end{array}$ & $\begin{array}{c}\% \\
\text { uniform }\end{array}$ \\
\hline$X$ & 92 & 4 & $96 \%$ & 92 & 8 & $91 \%$ & 92 & 1 & $97 \%$ \\
\hline $\mathrm{C}$ & 98 & 23 & $77 \%$ & 98 & 2 & $98 \%$ & 98 & 4 & $94 \%$ \\
\hline B & 26 & 4 & $85 \%$ & 26 & 4 & $85 \%$ & 26 & 0 & $100 \%$ \\
\hline $\mathrm{Y}$ & 14 & 0 & $100 \%$ & 14 & 0 & $100 \%$ & 14 & 0 & $100 \%$ \\
\hline
\end{tabular}


between stakeholder variables: X (stakeholder), B (culture), K1 (communication), K2 (conflict), C (collaborative) with Y1 (physical construction waste). Y2 (non-physical construction waste) to obtain the SEM-PLS model complete with all measurable indicators of each variable (model 1). After the calculation of PLS Algorithm, the outer loading value indicator $<0.40$ removed and calculated PLS Algorithm, the value of outer loading indicator $<0.70$ removed from the variable (model 2), as shown in Figure 2.

The standard loading factor is useful for assessing whether the construct has adequate discriminant validity. The standard loading factor describes the magnitude of the correlation of each measurement item by its loading factor at $>0.70$.

The goal is to determine whether the model is appropriate, 9 (nine) indicators removed: two collaborative variables and seven stakeholder variables.

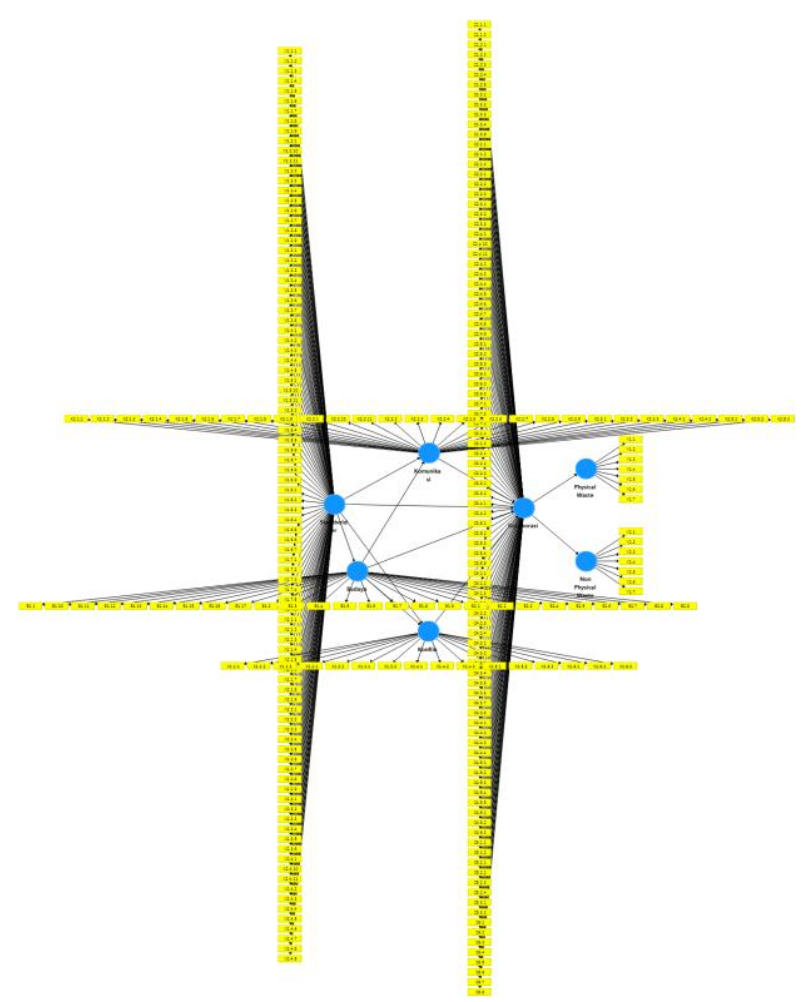

(a)

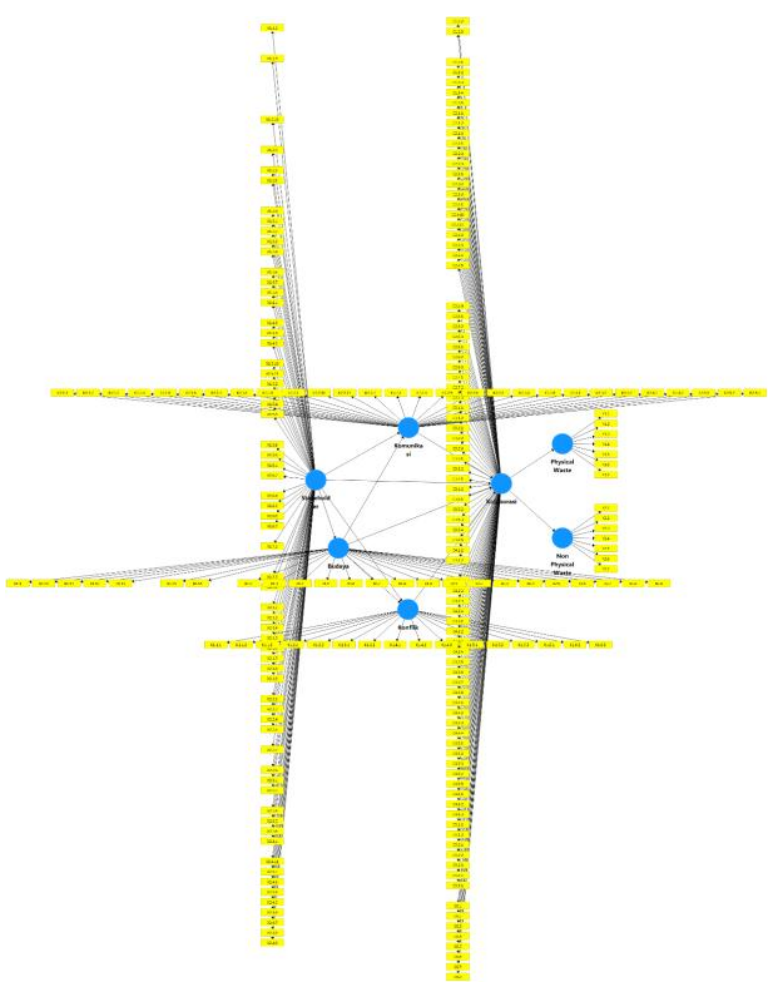

(b)

Figure 3 Change of variable after calculation result of PLS Algorithm before (a) and after (b)

\subsubsection{Validity test}

The loading factor test can also be printed out of Calculate PLS Bootstrapping command from Figure 3 to see the $T$ statistic value. An indicator that has a $T$ statistic value of $\geq 1,96$ is said to be valid. The indicator can also be expressed accurately if it has a value of $\mathrm{P} \leq 0.05$, so that all constructive construct indicators are valid and can be used to test the hypothesis in the formative measurement phase.

\subsubsection{Test reliability}

Evaluation of construct reliability value is measured by Cronbach's Alpha and Composite Reliability with calculating PLS Algorithm. The value of Cronbach's Alpha all constructs should be $\leq 0.70$. Table 4 shows the Cronbach's Alpha value for all constructs $\geq 0.70$, so it can be concluded that the indicator is consistent in measuring the construct.

As for Composite Reliability measurement, the entire construct has a value of $\geq 0.70$, so it can be concluded that indicators are consistent in measuring the constructs. AVE values can also be 
used to indicate the magnitude of the indicator variants contained by the construct. AVE critical value $\geq 0,50$, based on Table 4 .

Table 4 Test results construction reliability based on convergent validity

\begin{tabular}{lcccc}
\hline \multicolumn{1}{c}{ Variable } & $\begin{array}{c}\text { Cronbach's } \\
\text { Alpha }\end{array}$ & Rho A & $\begin{array}{c}\text { Composite } \\
\text { Reliability }\end{array}$ & $\begin{array}{c}\text { Average Variance } \\
\text { Extracted (AVE) }\end{array}$ \\
\hline Culture & 0.959 & 0.963 & 0.963 & 0.507 \\
Collaboration & 0.984 & 0.985 & 0.984 & 0.392 \\
Communication & 0.967 & 0.968 & 0.969 & 0.532 \\
Conflict & 0.946 & 0.948 & 0.953 & 0.559 \\
Non-Physical Waste & 0.899 & 0.908 & 0.920 & 0.624 \\
Physical Waste & 0.870 & 0.895 & 0.899 & 0.561 \\
Stakeholder & 0.975 & 0.976 & 0.976 & 0.308 \\
\hline
\end{tabular}

\subsubsection{Evaluation of structural model and hypothesis test}

In the evaluation phase, the structural model will be analyzed by looking at the significance of the relationship between constructs as shown by the T-statistic value generated from the output of the options calculate PLS $\rightarrow$ Bootstrapping. Bootstrapping is doing the calculation of the data to prove the hypothesis based on the result of t-statistics and P-value. The amount of influence between constructs and their interaction effects (moderation) is measured by the coefficient value of the path (path coefficient). Path coefficient that has t-statistic $\geq 1.96$ or has $\mathrm{P}$-value $\leq 0.05$ expressed significantly.

Table 5 Path coefficient

\begin{tabular}{lccccc}
\hline & $\begin{array}{c}\text { Original } \\
\text { Sample } \\
(\mathrm{O})\end{array}$ & $\begin{array}{c}\text { Sample } \\
\text { Mean }(\mathrm{M})\end{array}$ & $\begin{array}{c}\text { Standard } \\
\text { Deviation } \\
(\text { STDEV })\end{array}$ & $\begin{array}{c}\text { T Statistics } \\
(\mid \mathrm{O} / \mathrm{STDEV})\end{array}$ & $\begin{array}{c}\mathrm{P} \\
\text { Values }\end{array}$ \\
\hline Culture $\rightarrow$ Collaboration & 0.446 & 0.434 & 0.056 & 8.042 & 0.000 \\
Culture $\rightarrow$ Communication & 0.534 & 0.540 & 0.076 & 7.041 & 0.000 \\
Culture $\rightarrow$ Conflict & 0.180 & 0.181 & 0.115 & 1.567 & 0.118 \\
Collaboration $\rightarrow$ Non-physical Waste & 0.541 & 0.554 & 0.058 & 9.341 & 0.000 \\
Collaboration $\rightarrow$ Physical Waste & 0.546 & 0.559 & 0.056 & 9.817 & 0.000 \\
Communication $\rightarrow$ Collaboration & 0.195 & 0.193 & 0.068 & 2.855 & 0.004 \\
Conflict $\rightarrow$ Collaboration & 0.060 & 0.071 & 0.039 & 1.535 & 0.125 \\
Stakeholder $\rightarrow$ Culture & 0.605 & 0.618 & 0.051 & 11.827 & 0.000 \\
\hline Stakeholder $\rightarrow$ Collaboration & 0.376 & 0.377 & 0.043 & 8.636 & 0.000 \\
Stakeholder $\rightarrow$ Communication & 0.278 & 0.282 & 0.079 & 3.513 & 0.000 \\
Stakeholder $\rightarrow$ Conflict & 0.458 & 0.467 & 0.082 & 5.558 & 0.000 \\
\hline
\end{tabular}

Based on Table 5, the path coefficient can be use to test the hypothesis. The value of t-statistic and p-values determines the test results on 11 hypotheses. Hypothesis testing is done by using tvalue with significance level 0,05 . If the value of t-statistic $\geq 1.96$ or $\mathrm{p}$-value $\leq 0.05$, then $\mathrm{H} 0$ rejected (research hypothesis accepted).

This evaluation uses a bootstrapping procedure that aims to predict the relationship between latent variables used for the structural model. Assessment by looking at the percentage of variance described that is looking at the value of $\mathrm{R}^{2}$, for potential endogenous constituents Stone-Geisser's $=\mathrm{Q}^{2}$ to test predictive relevance and average variance extracted (AVE) for predictiveness by using resampling procedure. This procedure uses all the original samples for resampling back where with the record the record the amount should be more significant than the sample. 
Based on hypothesis test results, from eleven existing research hypotheses, the accepted hypothesis is 9 (Nine), while the rejected hypothesis is 2 (two). Of the nine accepted hypotheses, the path of variable that formed are:

Stakeholder $\rightarrow$ Culture $\rightarrow$ Collaboration $\rightarrow$ Physical waste

Stakeholder $\rightarrow$ Culture $\rightarrow$ Collaboration $\rightarrow$ Non-Physical waste

The meaning is that stakeholders have a positive influence on culture, and culture has a positive effect on collaboration, and collaboration has a positive impact on physical construction waste and collaboration have a positive effect on non-physical construction waste.

Stakeholder $\rightarrow$ Collaboration $\rightarrow$ Physical waste

Stakeholder $\rightarrow$ Collaboration $\rightarrow$ Non-Physical Waste

The meaning is that stakeholders have a positive influence on collaboration, and collaboration has a positive effect on physical construction waste and collaboration have a positive impact on non-physical construction waste. And this is already represented by the previous path.

Stakeholder $\rightarrow$ Conflict $\rightarrow$ Collaboration $\rightarrow$ Physical waste

Stakeholder $\rightarrow$ Conflict $\rightarrow$ Collaboration $\rightarrow$ Non-Physical Waste

The meaning is that stakeholders have a positive effect on the conflict, but the conflict has no impact on collaboration, and collaboration has a positive effect on physical construction waste and collaboration have a positive effect on non-physical construction waste. And this is already represented by the previous path.

Stakeholder $\rightarrow$ Communication $\rightarrow$ Collaboration $\rightarrow$ Physical waste

Stakeholder $\rightarrow$ Communication $\rightarrow$ Collaboration $\rightarrow$ Non-Physical waste

The meaning is that stakeholders have a positive influence on communication, communication has a positive effect on collaboration, and collaboration has a positive impact on physical construction waste and collaboration have a positive impact to non-physical construction waste. And this is already represented by the previous path. Thus the path that determines the success of reduction of construction waste is significantly influenced by stakeholders, culture, conflict, and communication.

\subsection{Discussion}

\subsubsection{Main platform for creating collaboration of parties}

Building collaboration is supported by a strong foundation; the hypothesized determinant variables are stakeholders, culture, communication and conflict. For collaboration to work effectively, mapping of its relevance to these variables is required, thus providing confidence that building good collaboration is based on understanding stakeholders; understanding the culture of the community; having the ability to manage communications; and, of course, managing conflict.

Stakeholders involved in design-building projects are both significant and key players, determining the success of a collaboration; these can be both internal and external stakeholders.

Culture consists of ethnic and corporate culture, and these two cultural indicators have a positive influence on the success of collaboration. Culture forms and is formed by stakeholders. Ethnic culture shapes their character, so that wherever they are, this cultural background greatly influences their character. A recent study conducted by Gustavsson and Gohary (2012) found that there was a wide range of boundaries encompassing facilitated activities and activities pursued during the design and production process, with three boundary range patterns having particular importance in efficient collaboration: geographical boundaries, professional boundaries and stakeholder boundaries. This study complements the concept of the boundary 
range with the addition of a cultural spanning boundary. The findings clearly explain that cultural factors are the most important aspect of the success of collaboration in Indonesia.

Conflict is a variable that negatively affects collaborative variables, meaning that any increase in conflict negatively affects the success of collaboration; any potential collapse of collaboration may often be due to increased conflict. Conflict management begins with planning for conflict, followed by its mapping, so that any causes of conflict are identified. Team building skills are also important in collaboration so that it can be maximized; strategies for resolving conflict include smoothing, withdrawal, compromise, forcing, problem-solving or confrontation.

Communication is a variable that has an effect on collaboration, meaning that any increase in communication positively affects its success (Edah, 2009). Therefore, the potential for successful collaboration is also due to improved communication. The task of collaborators is to build collaboration, an effective tool for the task of collaborators is to build collaboration, an effective tool for communication, if effective communication fails, it is difficult to make collaboration work.

\subsubsection{The importance of stakeholders in the design-build projects}

Stakeholders who are both parties involved in the designed build project are both significant and key players that determine the success of a collaboration. There is influence from stakeholders to culture, both ethnic culture and corporate culture. From stakeholder mapping based on Ackermann and Eden (2010), based on the power/interest grid, which describes the quadrants: players, sub-keys, context setter, and the crowd.

From this mapping of stakeholders, the great potential that will shape the culture in the designbuild project comes from the player's position, subject, and context-setting. Because significantly the characteristics of these stakeholders have at least one positive value, whether of interest or power. This strength will be able to shape the ethnic culture and corporate culture. So the ability of the collaborative manager or project manager becomes the determinant for the occurrence of ethnic culture or corporate culture that builds collaboration.

Stakeholders involved in design-build projects are important elements and key players who determine the success of collaboration. Communication can be formal or informal. The communications management plan is a document that contains guidance/direction on how to communicate in a project, including the communication needs of stakeholders; the information to be communicated, including its format, content, and level of detail; and the person responsible for providing the information.

At the same time, stakeholders are significant elements and also major players determining the occurrence of conflict, so this hypothesis proposes that stakeholders are very influential on conflict. Conflict can be functional or dysfunctional. Pondy (2012) believes that imbalances and problems stimulate development and creativity. This is in accordance with the Japanese proverb which states that by the time two bubbles come together, both will disappear. According to Gadde and Håkansson (1993), this can be illustrated by two axes, the first showing the degree of collaboration between the buyer and the seller, and the second indicating the degree of conflict with respect to the business relationship.

\subsubsection{Communication and conflict affect collaboration implementation of parties}

Culture can be both ethnic and corporate, and these two cultural indicators have a positive influence on the success of collaboration. Culture forms the pattern of stakeholder communication, so it is very influential in building good communication in collaboration. So the relationship between culture and communication in developing collaboration has a positive influence, or culture positively affects communication (Koentjaraningrat, 2009; Edah, 2009). 
Culture forms the pattern of stakeholder conflicts, and is very influential in the occurrence of conflict. There is great potential for conflict between cultures, but alignment and tolerance will reduce this in collaboration. So the relationship between culture and conflict in building collaboration has a positive influence, or culture positively affects conflict. According to the Japanese proverb, when two bubbles assemble, both will disappear from their original form. According to Gadde and Håkansson (1993). This means that different potential cultures will cause problems. This conflict is a variable that negatively affects collaboration. So the possible collapse of collaboration is due to increased conflict in the collaboration (Vaaland, 2004).

Communication is a variable that influences collaboration; increased communication affects its potential success. Human interaction has a key issue of conflict incidence that includes: Weak communication between disciplines, such as between engineering and production; Cultural and linguistic differences are emphasized on building business relationships; The buyer wants to communicate directly with sub-suppliers but is blocked by official barriers or the desire to avoid direct engagement.

\subsubsection{Collaboration model encourages waste construction reduction}

Collaboration is an important variable that affects the reduction of construction waste, any increase in better collaboration will positively impact the decline of physical construction waste (Nagapan et al., 2012). With collaboration, the physical work begins with a process involving all parties in planning, implementation, and supervision, so that the integration issues between the roles and functions of each stakeholder can be resolved early. The use of Building Information Modelling (BIM) software will be even better because each stakeholder can recognize each problem and solve it earlier.

Collaboration gives effect to the reduction of Non-physical construction waste. According to Nagapan et al. (2012), non-physical waste usually occurs during the construction process. Unlike waste materials, Non-physical waste is the time and cost to be spent on construction projects (Nagapan et al., 2012). Similarly, Alwi et al. (2002), researchers from Indonesia define waste not only related to waste of material but also other activities such as improvements, waiting times and delays. So Non-physical waste is a waste associated with the use of ineffective time, so the work/activities carried out over time work that should be useless time is due to the handling of inefficient materials, work methods are used inappropriately, the material quality is not appropriate standards, improper use of equipment and others (Alwi et al., 2002).

\section{CONCLUSION}

From the results of the discussion, it can be concluded several things as follows: (1) The primary foundation for creating successful stakeholder collaboration on the Designed-Build project consists of how to manage stakeholders, recognize and understand the cultural dimensions of both ethnic and corporate culture, understand conflict management and resolve conflicts when they occur, and maintain effective communication and tailored to the needs of the Design-Build project; (2) The importance of stakeholders in the case of the Design-Build project, judging by the conditions under which stakeholders deeply influence the culture that enables them to facilitate collaborative design-build projects.. Then to the stakeholders or parties involved in the Design Plan project is very prominent on communication and conflict, communication management related to the Design-Build project is very helpful in facilitating the flow of communication between the parties so that errors in communication can be minimized. The potential for conflict of stakeholders is very significant, therefore in the design project need to be wary of the conflict, so that the management of stakeholders is essential in the project Design-Build; (3) Communication and conflict affect the implementation of collaboration, where culture affects communication and conflict. Thus the potential for conflict in the collaboration of cultural background both ethnic culture and corporate culture can be 
avoided maximally; and (4) Collaboration model influences the reduction of construction waste, both physical construction waste and non-physical construction waste. The influence is very significant indicated by the statistic value of $\mathrm{t}=9.817$ for physical construction waste and $\mathrm{t}=$ 9.341 for non-physical construction waste.

\section{ACKNOWLEDGEMENT}

The authors would like to thank the financial support provided by University of Indonesia through the PITTA 2017 funding scheme under Grant number 861/UN2.R3.1/HKP.05.00/2017 Managed by the Directorate for Research and Public Services (DRPM) University of Indonesia.

\section{REFERENCES}

Ackermann, F., Eden, C., 2010. Strategic Management of Stakeholders: Theory and Practice. Long Range Planning, Volume 44(3), pp. 179-196

Alwi, S., Hampson, K., Mohamed, S., 2002. Non Value-Adding Activities in Australian Construction Projects. In: International Conference on Advancement in Design, Construction, Construction Management and Maintenance of Building Structure, Bali, 2728 March, Indonesia

Bakar, A. H. A., Cheen, K. S., Rahmawaty., 2011. Sustainable Housing Practices in Malaysian Housing Development: Towards Establishing Sustainability Index. International Journal of Technology, Volume 2(1), pp. 84-93

Baum, H., Katz, A., 2011. A Novel Methodology to Estimate the Evolution of Construction Waste in Construction Sites. Journal of Waste Management, Volume 31(2), pp. 353-358

Berawi, M.A., 2017. Designing National Policy and Strategies for Inclusive Development: Accelerating Infrastructure Development for Growth and Prosperity. International Journal of Technology, Volume 8(5), pp. 773-776

Bossink, B.A.G., Brouwers, H.J.H., 1996. Construction Waste: Quantification and Source Evaluation. Journal of Construction Engineering and Management, Volume 122(1), pp. $55-60$

Burgess, H., Burgess, G.M., 1997. Encyclopedia of Conflict Resolution. ABC-CLIO, Inc., Santa Barbara, California

Caltrans, 2007. Project Communication Handbook. Office of Project Management Process Improvement, 1120 N Street, Mail Station 28, Sacramento, CA 95814

Construction Industry Institute, 2018. Design/Build (Archived). Available online at https://www.construction-institute.org/resources/knowledgebase/knowledge-

areas/procurement-contracts/topics/rt-133

Coser, L.A., 1956. The Functions of Social Conflict. The Free Press, New York, USA

Edah, J., 2009. Analisis Hubungan Gaya Kepemimpinan dan Kompetensi Komunikasi dalam Organigasasi. Jurnal Ilmu Administrasi, Volume 6(4), pp. 370-380 (in Bahasa)

Egan, J., 1998. Rethinking Construction: The Report of the Construction Task Force. Department of the Environment, Transport and the Regions and HMSO, London, United Kingdom, England

Elmarsafi, G.M., 2008. Interorganizational Collaboration: Transformation Strategies to Reduce Construction Disputes in the Construction Industry. ProQuest LLC, Capella University, Minneapolis, Minnesota, USA

Erwin, M., 2012. Pendidikan Kewarganegaraan Republik Indonesia. PT Refika Aditama, Bandung, Indonesia, pp. 48-50 (in Bahasa)

Fisher, R., Ury, W.L., Patton, B., 1991. Getting to Yes: Negotiating Agreement without Giving In. Penguin Books, New York, USA 
Forbes, L.H., Ahmed, S.M., 2011. Modern Construction: Lean Project Delivery and Integrated Practices. CRC Press: Taylor and Francis Group, New York, USA

Gadde, L.E., Håkansson, H., 1993. Professional Purchasing. London Routledge, London, United Kingdom, England

Gustavsson, T.K., Gohary, H., 2012. Boundary Action in Construction Projects: New Collaborative Project Practices. International Journal of Managing Projects in Business, Volume 5(3), pp. 364-376

Hao, J.L.L, Hills, M.J., Shen, L.Y., 2008. Managing Construction Waste On-site through System Dynamics Modelling: The Case of Hong Kong. Engineering, Construction and Architectural Management, Volume 15(2), pp.103-113

Harshada, P., Pettitt, M., Wilson, J.R., 2011. Factors of Collaborative Working: A Framework for Collaboration Model. Applied Ergonomics, Volume 43(1), pp. 1-26

Hofstede, G., 2017. Get Hofstede. Available online at https://geert-hofstede.com/

Jepsen, A.L., Eskerod, P., 2009. Stakeholder Analysis in Projects: Challenges in using Current Guidelines in the Real World. International Journal of Project Management, Volume 27, pp. 335-343

Kadefors, A., 2004. Trust in Project Relationships - Inside the Black Box. International Journal of Project Management, Volume 22(3), pp. 175-182

Koentjaraningrat, 2009. Pengantar Ilmu Antropologi. Erlangga, Jakarta, Indonesia (in Bahasa)

Kofoworola, O.F., Gheewala, S.H., 2009. Estimation of Construction Waste Generation and Management in Thailand. Journal of Waste Management, Volume 29(2), pp. 731-738

Nagapan, S., Rahman, I.A., Asmi, A., 2012. Factors Contributing to Physical and Non-physical Waste Generation in Construction Industry. International Journal of Advances in Applied Sciences (IJAAS), Volume 1(1), pp. 1-10

Nicolajsen, H.W., 2007. ICT Use in Inter-organizational Collaboration: The Field of Construction. In: Proceedings of the $30^{\text {th }}$ Information System Research Seminar. Scandinavia: IRIS

Peng, C.L., Scorpio, D.E., Kibert, C.J., 1997. Strategies for Successful Construction and Demolition Waste Recycling Operations. Constructtion Management and Economics, Volume 15(1), pp. 49-58

Pondy, L.R., 2012. Organizational Conflict: Concepts and Models. Administrative Science Quarterly, Volume 12(2), pp. 296-320

Poon, C.S., 2007. Reducing Construction Waste. Waste Management, Volume 27(2), pp. 17151716

Schifrin, M., 2001. Partner or Perish. Forbes, pp. 26-28

Schmeer, K., 1999. Health Reform Tools Series: Guidelines for Conducting a Stakeholder Analysis. Partnerships for Health Reform Publication, Abt Associates, Inc., Bethesda, USA

Shen, L.Y., Tam, V.W.Y., Tam, C.M., Drew, D.S., 2004. Mapping Approach for Examining Waste Management on Construction Sites. Journal of Construction Engineering and Management, Volume 130(4), pp. 472-481

Shenkar, O., Yan, A., 2002. Failure as a Consequence of Partner Politics: Learning from the Life and Death of an International Cooperative Venture. Human Relations, Volume 55(5), pp. 565-601

Tam, V.W., Tam, C.M., 2008. Waste Reduction through Incentives: A Case Study. Building Research and Information Journal, Volume 36(1), pp. 37-43

Vaaland, T.I., 2004. Improving Project Collaboration: Start with the Conflicts. International Journal of Project Management, Volume 22(6), pp. 447-454 
Xue, Z. X., Ruixue, Y., Rabecca, J., Dai, J., 2014. Innovation in Construction:, A Critical Review and Future Research. International Journal of Innovation Science, Volume 6(2), pp. 111-126

Yasamis, F., Arditi, D., Mohammadi, J., 2002. Assessing Contractor Quality Performance. Construction Management and Economics, Volume 20(3), pp. 211-223

Yin, R.K., 2009. Case Study Research: Design and Methods. SAGE Publication, London, United Kingdom, England 